\title{
State of prediction of the critical thinking dispositions of primary school teacher candidates through their self-efficacy for STEM practices
}

\begin{tabular}{|c|c|}
\hline \multicolumn{2}{|c|}{$\begin{array}{l}\text { Sümeyye AYDIN GÜRLER* } \\
\text { Department of Mathematics and Science Education, Nizip Education Faculty, } \\
\text { Gaziantep University, Gaziantep, Turkey. } \\
\text { ORCID: 0000-0003-2651-4395 }\end{array}$} \\
\hline Article history & The aim of the present study was to identify the state of prediction of the \\
\hline $\begin{array}{l}\text { Received: } \\
01.09 .2021\end{array}$ & $\begin{array}{l}\text { critical thinking dispositions of primary school teacher candidates } \\
\text { through their self-efficacy for STEM. The study was designed subject to }\end{array}$ \\
\hline $\begin{array}{l}\text { Received in revised form: } \\
16.11 .2021\end{array}$ & $\begin{array}{l}\text { the correlational survey model with the sample group comprised of } 295 \\
\text { primary school teacher candidates continuing their education at the two } \\
\text { education faculties of a state university in Southeastern Anatolia Region }\end{array}$ \\
\hline $\begin{array}{l}\text { Accepted: } \\
16.11 .2021\end{array}$ & $\begin{array}{l}\text { of Turkey during the } 2020-2021 \text { academic year who were identified in } \\
\text { accordance with the proper sampling method. The data were collected }\end{array}$ \\
\hline Key words: & via, "Self-Efficacy Scale for STEM Practices" and "Critical Thinking \\
\hline $\begin{array}{l}\text { Self-efficacy for STEM } \\
\text { practices; } \\
\text { Critical thinking disposition; } \\
\text { Primary school teacher } \\
\text { candidate }\end{array}$ & $\begin{array}{l}\text { Disposition Scale". Descriptive analysis was used for determining the } \\
\text { self-efficacy for STEM practices and critical thinking dispositions of } \\
\text { primary school teacher candidates; correlation analysis was used for } \\
\text { illustrating the relationship between self-efficacy for STEM practices and } \\
\text { critical thinking disposition along with its sub-dimensions; linear } \\
\text { regression analysis was used for identifying the state of prediction for } \\
\text { critical thinking disposition and its sub-dimensions through self-efficacy } \\
\text { for STEM practices whereas stepwise multiple regression analysis was } \\
\text { used for determining the state of prediction for critical thinking } \\
\text { disposition through gender and self-efficacy for STEM practices sub- } \\
\text { dimensions. Based on the analysis results, the self-efficacy for STEM } \\
\text { practices and critical thinking dispositions of teacher candidates are at a } \\
\text { good level. There is a positive and statistically significant correlation } \\
\text { between self-efficacy for STEM practices and critical thinking } \\
\text { disposition and its sub-dimensions. It was illustrated that self-efficacy for } \\
\text { STEM practices is a statistically significant predictor of critical thinking } \\
\text { disposition and its sub-dimensions and that tenacity-patience was the } \\
\text { variable that was predicted the most among these sub-dimensions whilst } \\
\text { the stepwise multiple regression analysis set forth that self-efficacy belief } \\
\text { was the predictor that made the highest contribution to critical thinking } \\
\text { disposition. Various suggestions were made based on the results of the } \\
\text { study. }\end{array}$ \\
\hline
\end{tabular}

\section{Introduction}

Technology is advancing rapidly in the 21 st century expressed as the information age or the digital age. Therefore, the need for individuals who can adopt to this century is

\footnotetext{
* Correspondency: s.aydingurler@gmail.com
} 
increasing rapidly. Individuals are required to possess various 21 st century skills such as critical and analytical thinking, creativity, entrepreneurship, problem solving, accessing and using information, cooperation, leadership, written and verbal communication and curiosity (Thomas, 2014; Wagner, 2008). The foundations of the education that will provide these skill sets to the individuals were first laid down in America in 2001 under the name of STEM which is the abbreviation for the disciplines of Science, Technology, Engineering and Mathematics (Zollman, 2012). Countries that wish to have a strong economy and a good standing in the fields of science and technology should give importance to STEM education as well as educating individuals with 21 st century skills. However, it is observed especially according to the placement based on university examination results in our country that placement towards the fields of STEM is relatively less (Çolakoğlu \& Günay-Gökben, 2017). It may be difficult for our country to reach its 2023 goals if this situation persists. The prevalent situation in our country indicates the necessity of taking measures with regard to STEM education. One of the measures to be taken is ensuring that the teachers to instill a STEM conscience in the students will have self-efficacy for STEM practices during their undergraduate education as well as the 21 st century skills which are among the acquisitions of this education.

\section{Self-efficacy for STEM practices}

The concept of self-efficacy first identified by Bandura (1997) is defined as the identification by an individual of the required steps in order to display the required performance in a subject and his/her capacity to actualize these steps. If an individual has high self-confidence or motivation with regard to successfully completing a task then he/she will have a high self-efficacy level; whereas if the self-confidence or motivation is low then he/she will have a low self-efficacy level (Dembo, 2004). Insufficiency experienced in a certain subject by teacher candidates during their undergraduate education will reflect as anxiety, concerns and stress in their professional lives. Teacher candidates need to have sufficient selfefficacy in subjects required by their professional lives in order to feel competent (Yaman, Özdemir, \& Akar-Vural, 2018). Self-efficacy for STEM practices is among the self-efficacies that teacher candidates should have considering the age that we live in. Because the effortless implementation of STEM education in classroom environments depends on the knowledge and beliefs of the teachers on this type of education (Ring, Dare, Crotty, \& Roehrig, 2017). STEM teachers of the respective courses undoubtedly have the highest responsibility in integrating STEM disciplines and presenting to the students. Therefore, it seems important to increase the self-efficacy for STEM practices of teacher candidates considered as the teachers of the future (Fulton, Doerr, \& Britton, 2010).

\section{Critical thinking disposition}

Critical thinking is among the skills expressed as 21 st century skills, life skills or higher order thinking skills. Ennis (1985) and Facione (2007) conducted many studies on critical thinking and expressed critical thinking as in-depth consideration of one's decisions or actions. Critical thinking encompasses questioning whether the information is reliable or not in addition to the states of accepting or rejecting the information (Aizikovitsh-Udi \& Amit, 2011). Whereas critical thinking disposition is defined as the inclination or attitude of an individual in order to think critically (Yeh, 1997). According to Facione (2007), critical thinking disposition and critical thinking skill have the same meaning. That is, while having a critical thinking disposition does not necessarily mean that one has critical thinking skills; the presence of critical thinking skill is not always equivalent to having a disposition to use that skill. However, various researchers focusing on critical thinking disposition have stated the 
urgency to focus more on critical thinking disposition in order to put forth the attitude and emotional aspects of critical thinking (Facione 2007; Yeh, 2004). An individual has to have critical thinking disposition to be able to think critically. Because this will also make a significant impact on the ability to be critical (Öztürk, 2018).

\section{Self-efficacy for STEM practices and critical thinking}

It can be considered that the number of unemployed individuals will increase with the use of technological devices in place of manpower subject to technological advancements. Thus, providing STEM education to children starting for an early age is important for ensuring that they are able to find a place for themselves amidst the vocations of the future (Çolakoğlu \& Günay-Gökben, 2017). STEM education corresponds to associating science, technology, engineering, and mathematics while teaching these subjects to children (Meng, Idris, \& Kwan, 2014). At least two disciplines (Science, Mathematics, Engineering, Technology) should be integrated in this approach (Çorlu, Capraro, \& Capraro, 2014). Teaching STEM disciplines without any integration leads to failures in teaching these disciplines in the desired manner (Sanders, 2013). In the meantime, this also makes it difficult for students to acquire 21st century skills. Because STEM education plays a major role in ensuring that students acquire 21 st century skills such as critical and analytical thinking, creativity, establishing communication and problem solving (Meyrick, 2011; Şahin, Ayar, \& Adigüzel, 2014; Wai, Lubinski, \& Benbow, 2010). According to Thomas (2014), STEM approach has many objectives such as increasing the scientific and technological literacy of individuals, increasing awareness towards technology and engineering, increasing the interest towards an engineering career, supporting countries in making innovations that will lead to economic gains and ensuring that individuals acquire skills such as critical thinking and problem solving. One of the major reasons why many countries have adopted to STEM education and strived to increase the quality of this type of education is that STEM education supports the development of 21st century skills (Stinson, Harkness, Meyer, \& Stallworth, 2009). The role of teachers in implementing the curriculum in teaching science courses has been identified as guiding students regarding the integration of science, mathematics, technology, and engineering while helping them to reach a level at which they are able to develop products, apply higher order thinking, make innovations and inventions (Ministry of National Education [MoNE], 2018). One of these higher order thinking skills is critical thinking. A teacher who wishes to provide STEM education to his/her students for ensuring that they attain critical thinking skills should first ensure that he/she has the required selfefficacy for STEM practices and critical thinking disposition.

\section{Related Literature}

It is observed as a result of conducting a survey of the related national and international literature that many studies have been carried out on STEM education and selfefficacy for STEM practices (Abac1, 2020; Bakırc1 \& Kutlu, 2018; Boynukara, Deniz, Tüysüz, \& 2020; Bölükbaş1 \& Görgülü-Arı, 2019; Brown, Concannon, Marx, Donaldson, \& Black, 2016; Buechel, 2021; Cho \& Lee, 2013; Çevik, Danıştay \& Yağc1, 2017; ErtuğrulAkyol, 2020; Faber, Alanda, Eric, \& Wiebe, 2013; Gelen, Akçay, Tiryaki, \& Benek, 2019; Haciömeroğlu, 2020; Koçulu \& Topçu, 2021; Önen-Öztürk, 2019; Öztürk, 2018; Öztürk, Yılmaz-Tüzün, \& Çakır-Yıldırım, 2019; Saleh, 2016; Timur \& İnançlı, 2018; Timur \& Belek, 2020; Yaman et al., 2018). However, it is observed that international studies have mostly focused on students while national studies have generally focused on science, mathematics, information technology teachers as well as science teacher candidates. Whereas it is also understood that studies on self-efficacy for STEM practices are mostly scale development 
studies (Gelen, Akçay, Tiryaki, \& Benek, 2019; Hacıömeroğlu, 2020; Luo, So, Li, \& Yao, 2020; Yaman et al., 2018). It is also observed that there is a limited number of studies related to STEM education which have been conducted with primary school teacher candidates (Adams, Miller, Saul, \& Pegg, 2014; Hacıömeroğlu \& Bulut, 2016; Haciömeroğlu, 2018; Kim \& Bolger, 2017). Even though primary school teacher undergraduate program does not include a course on STEM education, primary school teacher candidates learn how to develop materials in disciplines such as science and mathematics and how to implement education technologies during various courses (such as science teaching and mathematics teaching). Therefore, it is considered that primary school teacher candidates are among the best target groups for the effective implementation of STEM education while teaching (Haciömeroğlu, 2018). Science and engineering practices are included in the applied science unit of the science teaching program starting from the $4^{\text {th }}$ grade level and including the $8^{\text {th }}$ grade level. Hence, it can be put forth that conducting STEM related studies with primary school teachers and primary school teacher candidates is important since it is considered that the primary school teachers will be the first to integrate and teach the disciplines of science, mathematics, technology, and engineering to the students. In addition to providing field information in science education, the importance of teaching thinking skills considered as life skills and the improvement of such thinking skills are also emphasized as part of the science curriculum (Barak \& Shakhman, 2008). Critical thinking is one of these skills. Analytical thinking, critical thinking and reasoning skills of individuals can be increased through STEM education that adopts an interdisciplinary approach (Yaman et al., 2018). Hence, it can be stated that the STEM self-efficacies of teacher candidates will predict their critical thinking dispositions. Literature survey illustrated that no studies have been conducted on thinking skills (analytical thinking, critical thinking, reasoning and alike) that may have an impact on self-efficacy for STEM practices. In this regard, it is considered that the present study will contribute to the relevant literature.

The aim of the study was to examine the state of the prediction of critical thinking dispositions of primary school teacher candidates by their self-efficacy for STEM practices. The following sub-problems have been put forth for this purpose:

- What are the perception levels of primary school teacher candidates towards selfefficacy for STEM practices and critical thinking dispositions?

- Is there a statistically significant correlation between the self-efficacy for STEM practices of primary school teacher candidates and critical thinking disposition and its sub-dimensions?

- Are the self-efficacy for STEM practices of primary school teacher candidates statistically significant predictors of critical thinking dispositions in general?

- Are the self-efficacy for STEM practices of primary school teacher candidates statistically significant predictors of the sub-dimensions of critical thinking disposition (metacognition, flexibility, systematicity, tenacity and patience, open mindedness)?

- Do the gender of primary school teacher candidates together with their self-efficacy for STEM practices sub-dimensions predict critical thinking disposition in a statistically significant manner? 


\section{Method}

\section{Research Design}

Correlational survey model was used in the present study since it was aimed to examine the correlation between self-efficacy for STEM practices and critical thinking disposition. The reason for preferring this model in the present study was to measure two or more variables to identify whether they are correlated or not (Lodico, Spaulding, \& Voegtle, 2010). While it is difficult to talk about a cause-and-effect relationship in this model, certain predictions can be made based on the cause and effect relationship between variables (Fraenkel \& Wallen, 2019).

\section{Population and Sample Group}

The study population was comprised of a total of 477 primary school teacher candidates at the two education faculties of a state university at the Southeastern Anatolia Region during the 2020-2021 academic year. It was aimed to reach the entire population, however 313 primary school teacher candidates volunteered to take part in the study. Therefore, the sample group of the study consisted of 313 primary school teacher candidates continuing their education at these education faculties who were identified based on the proper sampling method. Of the implemented scales, 295 were included in the analysis. It was observed as a result of the calculations that the sample group size (95\% confidence level and $\alpha=.05$ statistically significance) was sufficient (Field, 2009; Özdamar, 2003). Table 1 presents the characteristics of the participants.

Table 1. Participant characteristics

\begin{tabular}{llll}
\hline Values & Groups & $\mathrm{f}$ & $\%$ \\
\hline \multirow{2}{*}{ Gender } & Female & 203 & 68.80 \\
& Male & 92 & 31.20 \\
\hline \multirow{3}{*}{ Education year } & $1^{\text {st }}$ year & 75 & 25.40 \\
& $2^{\text {nd }}$ year & 77 & 26.10 \\
& $3^{\text {rd }}$ year & 75 & 25.40 \\
& $4^{\text {th }}$ year & 68 & 23.10 \\
\hline \multirow{3}{*}{ Age } & $17-18$ & 16 & 5.40 \\
& $19-20$ & 110 & 37.30 \\
& $21-22$ & 97 & 32.90 \\
& $23-24$ & 46 & 15.60 \\
& $25-26$ & 18 & 6.10 \\
\hline
\end{tabular}

It was observed when Table 1 was examined that $68.80 \%$ of the participant teacher candidates were female and $31.20 \%$ were male. Regarding the education year, $25.40 \%$ of the participants were continuing their 1st year education; $26.10 \%$ were continuing their 2 nd year education; $25.40 \%$ were continuing their 3 rd year education and $23.10 \%$ were continuing their 4th year education. It was observed when the age interval was considered that $5.40 \%$ were in the 17-18 age interval; $37.30 \%$ were in the $19-20$ age interval; $32.90 \%$ were in the $21-22$ age interval; $15.60 \%$ were in the $23-24$ age interval; $6.10 \%$ were in the $25-26$ age interval and $2.70 \%$ were in the 27 and above age interval. 


\section{Data Collection Tools}

"Personal Information Form", "Self-Efficacy Scale for STEM Practices" and "Critical Thinking Disposition Scale" were used for data collection.

\section{Self-Efficacy Scale for STEM Practices}

Developed by the Friday Institute for Educational Innovation (2012), the Self-Efficacy for STEM Practices and Attitude Scale was adopted into Turkish by Gelen et al. (2009) for identifying only the level of self-efficacy. The scale consisted of 12 items and two subdimensions (self-efficacy belief in science education and expectations from science education). The scale is a 5-point Likert type scale in the form of "1- I completely disagree", "2- I disagree", "3- I am indecisive", "4- I agree" and "5- I completely agree" and includes no reverse items. The reliability of the scale was attained through the test-re-test method and by calculating the internal consistency coefficient with the Cronbach alpha value for the general scale calculated as .808. Factor analysis (EFA and CFA) was conducted for construct validity purposes. The validity and reliability studies were repeated during the present study. Cronbach alpha value calculated for scale reliability was .811 for the scale in general. Confirmatory factor analysis (CFA) was conducted for the construct validity of the scale. Difference in opinions was observed as a result of the literature survey conducted on which of the goodness of fit values are more reliable and thus on which of these values should be reported. Moreover, it is suggested to report $\chi^{2}$ and the related $\mathrm{p}$ value, $\chi^{2} / \mathrm{df}, \mathrm{CFI}$, SRMR and RMSEA goodness of fit indices if a calculation method such as maximum likelihood (ML) has been used in the study along with a wide sample group ( $\mathrm{N}>250)$ (Gürbüz, 2019; Kline, 2016). Therefore, the aforementioned goodness of fit values were reported in the present study as well. Goodness of fit values for the model were as follows: $\chi^{2}=126.429, \chi^{2} / \mathrm{df}=2.479$, $p=0.00, \mathrm{CFI}=0.945, \mathrm{SRMR}=0.0597$ and $\mathrm{RMSEA}=0.071$. These values are at acceptable levels (Gürbüz, 2019, p.34). Hence, the previously identified scale factor structure (two factor model) has been verified in the study sample group as well.

\section{Critical Thinking Disposition Scale}

The scale developed by Semerci (2016) is the revised version of the Critical Thinking Scale (Semerci, 2000). The scale consisted of 49 items and five sub-dimensions (metacognition, systematicity, flexibility, open mindedness, tenacity-patience). The scale is a 5-point Likert type scale in the form of "1- I completely disagree", "2- I mostly disagree", "3I partially agree", "4- I mostly agree" and "5- I completely agree" and includes no reverse items. The reliability of the scale was calculated via the test-re-test method and the internal consistency coefficient with the Cronbach alpha value for the general scale calculated as .963 . Factor analyses (EFA and CFA) were conducted to attain construct validity. The validity and reliability studies were repeated for the scale during the present study. The Cronbach alpha value calculated for scale reliability was .942 for the scale in general. Confirmatory factor analysis (CFA) was carried out for the construct validity of the scale. Goodness of fit values for the model were: $\chi^{2}=774.058, \chi^{2} / \mathrm{df}=1.834, \mathrm{p}=0.00, \mathrm{CFI}=0.908, \mathrm{SRMR}=0.0472$ and $\mathrm{RMSEA}=0.053$. These acceptable values indicate that the previously identified scale factor structure (five factor model) has been verified in the study sample group as well (Gürbüz, 2019, p.34).

\section{Data Analysis}

SPSS 21.0 (for calculating descriptive statistics, for identifying the Pearson product moment correlation coefficient and regression analyses) and AMOS 21.0 (for CFA carried out 
for construct validity) statistical software were used for data analysis. Descriptive statistics was used for identifying the self-efficacy for STEM practices and critical thinking dispositions of primary school teacher candidates; correlation analysis was used for identifying the correlation between the self-efficacy for STEM practices and critical thinking disposition and its sub-dimensions. Whereas the values suggested by Pallant (2016) were taken into consideration for interpreting the correlation coefficients (low correlation if correlation coefficient is between .10 and .29; moderate correlation if correlation coefficient is between .30 and .49; high correlation if the correlation coefficient is between .50 and 1.0). Individuals should be open minded, should have characteristics such as tenacity, systematicity and metacognition in order to ensure that STEM contains the integration of information from different disciplines (Science, Technology, Engineering, Mathematics) and to ensure that the integration can be conducted properly. Hence, simple linear regression analysis was conducted during the present study since it was considered that it is important to identify the state of predicting self-efficacy for STEM practices critical thinking disposition, metacognition, flexibility, systematicity, tenacity-patience and open mindedness. In addition, stepwise multiple regression analysis was used for identifying the state of prediction of critical thinking disposition by gender and self-efficacy for STEM practices sub-dimensions. Certain assumptions should be tested in order to conduct simple and multiple regression analyses on the dataset. Regarding the simple linear regression analysis it was observed based on the normality test results for the predictor and predicted variables that the distribution is normal and scattering diagram was examined to infer that there is a linear correlation between the predictor and the predicted variables. Outliers, linearity and normality, assumptions of homoscedasticity and multicollinearity were controlled prior to the multiple regression analysis. First, a total of 18 outliers were identified and cleared which prevent the normal distribution of the data. Afterwards, skewness and kurtosis values were calculated which were observed to be in the range -1.5 and +1.5 . It can be stated based on these findings that the data are distributed normally (Tabachnick \& Fidell, 2013). The following steps were taken with regard to the multicollinearity problem: double correlations between the predictor variables were examined and it was observed that the correlation is smaller than .90. In addition, it was also observed that the variance incremental factors are smaller than 10 and that the tolerance values are greater than .10. Thus, it can be stated that there is no multicollinearity problem (Büyüköztürk, 2003).

\section{Results}

\section{Self-efficacy for STEM Practices and Critical Thinking Dispositions Perception Levels of Teacher Candidates}

Table 2 presents the results for the descriptive analysis conducted for determining the self-efficacy for STEM practices and critical thinking dispositions perception levels of primary school teacher candidates.

Table 2. Self-efficacy for STEM practices and critical thinking disposition descriptive analysis

\begin{tabular}{lllll}
\hline Variables & $\mathbf{N}$ & $\bar{X}$ & SS & Std. Error \\
\hline 1. Self-efficacy for STEM practices & 295 & 3.87 & .47 & .02 \\
2. Critical thinking disposition & 295 & 4.08 & .45 & .02 \\
\hline
\end{tabular}

It was considered when the arithmetic mean scores presented in Table 2 were interpreted that 
both scales have been responded in 5-point Likert type. Therefore, the self-efficacy for STEM practices and critical thinking dispositions of the teacher candidates who took part in the study were at a "good" level $(\overline{\mathrm{X}}=3.87 ; \overline{\mathrm{X}}=4.08)$.

\section{Correlation Between the Self-efficacy for STEM Practices and Critical Thinking Disposition and Its Sub-Dimensions for Teacher Candidates}

Table 3 presents the results for the correlation analysis conducted in order to identify the correlation between the self-efficacy for STEM practices and critical thinking disposition and its sub-dimensions for primary school teacher candidates.

Table 3. Correlation analysis for the self-efficacy for STEM practices and critical thinking disposition and its sub-dimensions

\begin{tabular}{llllllll}
\hline Variables & 1 & 2 & 3 & 4 & 5 & 6 & 7 \\
\hline 1. Metacognition & 1 & & & & & & \\
2. Flexibility & $.551^{* *}$ & 1 & & & & & \\
3. Systematicity & $.682^{* *}$ & $.588^{* *}$ & 1 & & & & \\
4. Tenacity-patience & $.640^{* *}$ & $.480^{* *}$ & $.709^{* *}$ & 1 & & & \\
5. Open mindedness & $.536^{* *}$ & $.432^{* *}$ & $.583^{* *}$ & $.503^{* *}$ & 1 & & \\
6. Critical thinking disposition & $.862^{* *}$ & $.684^{* *}$ & $.911^{* *}$ & $.850^{* *}$ & $.703^{* *}$ & 1 & \\
7. Self-efficacy for STEM practices & $.416^{* *}$ & $.319^{* *}$ & $.435^{* *}$ & $.445^{* *}$ & $.330^{* *}$ & $.488^{* *}$ & 1 \\
\hline
\end{tabular}
${ }^{*} \mathrm{p}<.05,{ }^{* *} \mathrm{p}<.01$

The correlation coefficients in Table 3 illustrate that there is a positive and moderate relationship between self-efficacy for STEM practices and critical thinking disposition $(\mathrm{r}=.488, \mathrm{p}<.01)$. In addition, it was also observed that there is a positive and moderate relationship between self-efficacy for STEM practices and the metacognition $(\mathrm{r}=.416, \mathrm{p}<.01)$, flexibility $(\mathrm{r}=.319, \mathrm{p}<.01)$, systematicity $(\mathrm{r}=.435, \mathrm{p}<.01)$, tenacity-patience $(\mathrm{r}=.445, \mathrm{p}<.01)$, open mindedness $(\mathrm{r}=.330, \mathrm{p}<.01)$ sub-dimensions of critical thinking disposition. Hence, it can be interpreted that while the increase in the self-efficacy for STEM practices of primary school teacher candidates results in an increase in critical thinking dispositions; while decrease in self-efficacy for STEM practices may lead to a decrease in critical thinking dispositions.

\section{The State of Prediction for Critical Thinking Dispositions by the Self-efficacy for STEM Practices of Primary School Teacher Candidates}

Results for the simple linear regression analysis conducted for the general prediction state of critical thinking dispositions by the self-efficacy for STEM practices of primary school teacher candidates are presented in Table 4.

Table 4. Simple linear regression analysis for the prediction state of critical thinking disposition by self-efficacy for STEM practices

\begin{tabular}{llllll}
\hline Variable & $\mathrm{B}$ & Standard error & $\beta$ & $\mathrm{t}$ & $p$ \\
\hline Constant & 2.269 & .191 & & 11.877 & .000 \\
Self-efficacy for STEM practices & .468 & .049 & .488 & 9.563 & $.000^{*}$ \\
\hline $\mathrm{R}=.488$ & $\mathrm{R}^{2}=.238$ & & & & \\
$F_{(1,293)=91.441}$ & $p=.000$ & & & & \\
\hline${ }^{*} \mathrm{p}<.05$ & & & &
\end{tabular}

It was observed as a result of the regression analysis conducted for identifying how self- 
efficacy for STEM practices predicts critical thinking disposition that self-efficacy for STEM practices critical thinking disposition was a statistically significant predictor $(\mathrm{R}=.488$, $\left.\mathrm{R}^{2}=.238, F_{(1,293)}=91.441, \mathrm{p}<.05\right)$. Self-efficacy for STEM practices explains $23 \%$ of critical thinking disposition.

\section{Prediction State of the Critical Thinking Disposition Sub-Dimensions by the Self- efficacy for STEM Practices of Primary School Teacher Candidates}

Table 5 presents the simple linear regression analysis results regarding the prediction state of the critical thinking disposition sub-dimensions of metacognition, flexibility, systematicity, tenacity-patience and open mindedness by the self-efficacy for STEM practices of primary school teacher candidates.

Table 5. Simple linear regression analysis for the prediction state of the critical thinking disposition sub-dimensions by the self-efficacy for STEM practices

\begin{tabular}{|c|c|c|c|c|c|c|}
\hline $\begin{array}{l}\text { Critical thinking } \\
\text { disposition } \\
\text { Dimensions }\end{array}$ & Variable & B & Standard error & B & $\mathrm{t}$ & $p$ \\
\hline \multirow{4}{*}{ Metacognition } & Constant & 2.577 & .207 & & 12.474 & .000 \\
\hline & $\begin{array}{l}\text { Self-efficacy for STEM } \\
\text { practices }\end{array}$ & .414 & .053 & .416 & 7.820 & $.000^{*}$ \\
\hline & $\mathrm{R}=.416$ & $\mathrm{R}^{2}=.173$ & & & & \\
\hline & $F=(1,293)=61.151$ & $p=.000$ & & & & \\
\hline \multirow{4}{*}{ Flexibility } & Constant & 2.888 & .236 & & 12.216 & .000 \\
\hline & $\begin{array}{l}\text { Self-efficacy for STEM } \\
\text { practices }\end{array}$ & .349 & .061 & .319 & 5.757 & $.000^{*}$ \\
\hline & $\mathrm{R}=.319$ & $\mathrm{R}^{2}=.102$ & & & & \\
\hline & $F=(1,293)=33.148$ & $p=.000$ & & & & \\
\hline \multirow{4}{*}{ Systematicity } & Constant & 1.990 & .245 & & 8.113 & .000 \\
\hline & $\begin{array}{l}\text { Self-efficacy for STEM } \\
\text { practices }\end{array}$ & 0.520 & .063 & .435 & 8.271 & $.000^{*}$ \\
\hline & $\mathrm{R}=.435$ & $\mathrm{R}^{2}=.189$ & & & & \\
\hline & $F=(1,293)=68.414$ & $p=.000$ & & & & \\
\hline \multirow{4}{*}{$\begin{array}{l}\text { Tenacity } \\
\text { patience }\end{array}$} & Constant & 2.030 & .239 & & 8.504 & .000 \\
\hline & $\begin{array}{l}\text { Self-efficacy for STEM } \\
\text { practices }\end{array}$ & 0.520 & .061 & .445 & 8.502 & $.000^{*}$ \\
\hline & $\mathrm{R}=.445$ & $\mathrm{R}^{2}=.198$ & & & & \\
\hline & $F=(1,293)=72.292$ & $p=.000$ & & & & \\
\hline \multirow{4}{*}{ Open mindedness } & Constant & 2.122 & .309 & .330 & 6.864 & .000 \\
\hline & $\begin{array}{l}\text { Self-efficacy for STEM } \\
\text { practices }\end{array}$ & .474 & .079 & & 5.981 & $.000^{*}$ \\
\hline & $\mathrm{R}=.330$ & $\mathrm{R}^{2}=.109$ & & & & \\
\hline & $F=(1,293)=35.771$ & $p=.000$ & & & & \\
\hline
\end{tabular}

${ }^{*} \mathrm{p}<.05$

It was observed as a result of the regression analysis for identifying how self-efficacy for STEM practices predicts metacognition, flexibility, systematicity, tenacity-patience and open mindedness that self-efficacy for STEM practices is a statistically significant predictor of metacognition $\left(\mathrm{R}=.416, \mathrm{R}^{2}=.173, F_{(1,293)}=61.151, \mathrm{p}<.05\right)$, flexibility $\left(\mathrm{R}=.349, \mathrm{R}^{2}=.102, F\right.$ $(1,293)=33.148, \mathrm{p}<.05)$, systematicity $\left(\mathrm{R}=.435, \mathrm{R}^{2}=.189, F_{(1,293)}=68.414, \mathrm{p}<.05\right)$, tenacitypatience $\left(\mathrm{R}=.445, \mathrm{R}^{2}=.198, F_{(1,293)}=72.292, \mathrm{p}<.05\right)$ and open-mindedness $\left(\mathrm{R}=.330, \mathrm{R}^{2}=.109\right.$, 
$\left.F_{(1,293)}=35.771, \mathrm{p}<.05\right)$. Self-efficacy for STEM practices explains $19 \%$ of tenacity and patience; $18 \%$ of systematicity; $17 \%$ of metacognition; $10 \%$ of flexibility and open mindedness.

\section{Prediction State of the Critical Thinking Disposition by Gender and Self-efficacy for STEM Practices Sub-Dimensions of Primary School Teacher Candidates}

Table 6 presents the stepwise multiple regression analysis results regarding the prediction state of the critical thinking disposition by gender and self-efficacy for STEM practices sub-dimensions (self-efficacy belief in science education and expectations from science education) of primary school teacher candidates.

Table 6. Stepwise multiple linear regression analysis for the prediction of critical thinking disposition by gender and self-efficacy for STEM practices sub-dimensions

\begin{tabular}{|c|c|c|c|c|c|c|c|}
\hline Model & $\begin{array}{l}\text { Predicting } \\
\text { variable }\end{array}$ & Standardized $\beta$ & $\mathrm{t}$ & $\mathrm{p}$ & $\mathrm{F}$ (variable) & $\mathrm{R}^{2}$ & Increase in $\mathrm{R}^{2}$ \\
\hline 1 & $\begin{array}{l}\text { Self-efficacy } \\
\text { belief }\end{array}$ & .528 & 10.647 & $.000^{*}$ & 113.366 & .279 & .279 \\
\hline \multirow[t]{2}{*}{2} & $\begin{array}{l}\text { Self-efficacy } \\
\text { belief }\end{array}$ & .505 & 10.093 & $.000^{*}$ & \multirow[t]{2}{*}{6.560} & \multirow[t]{2}{*}{295} & \multirow[t]{2}{*}{.016} \\
\hline & Expectation & .128 & 2.561 & $.011^{*}$ & & & \\
\hline
\end{tabular}

It was observed when the stepwise multiple regression analysis results in Table 6 were examined that; self-efficacy belief is the predictor in the first stage of the model with the highest contribution to critical thinking disposition. Accordingly, the contribution of selfefficacy belief to the total variance regarding critical thinking disposition is about $28 \%$ and this value is statistically significant $\left(\mathrm{R}=.528, \mathrm{R}^{2}=.279, \mathrm{~F}(1,293)=113.366, \mathrm{p}<.05\right)$. Hence, the correlation value between self-efficacy belief and critical thinking disposition in science education was high, positive, and statistically significant as $.528(\mathrm{p}<.01)$. In the second stage, the variable of the expectation as a result of science education was included to the model in addition to the self-efficacy predictor. The additional contribution made by this predictor to explaining total variance is $2 \%$ with both of these predictors explaining about $30 \%$ of the total variance $\left(\mathrm{R}=.543, \mathrm{R}^{2}=.295, \mathrm{~F}(1,292)=6.560, \mathrm{p}<.05\right)$. Moreover, the correlation value between expectation and critical thinking disposition was small, positive and statistically significant as $.221(\mathrm{p}<.01)$. Gender (representative variable) was included to the model in the third stage in addition to the self-efficacy belief and expectation variables. It was observed that this predictor variable did not make a statistically significant contribution to the total variance regarding critical thinking disposition $\left(\mathrm{R}=.544, \mathrm{R}^{2}=.296, \mathrm{~F}(1,291)=.443, \mathrm{p}=.506>.05\right)$. Hence, this variable was excluded from the model.

\section{Discussion and Conclusions}

The perceptions of primary school teacher candidates towards self-efficacy for STEM practices and critical thinking dispositions were first identified in the present study conducted for identifying the state of prediction of the critical thinking dispositions of primary school teacher candidates by their self-efficacy for STEM practices. It was observed that the selfefficacy for STEM practices of teacher candidates is at a "good" level. Öztürk et al. (2019) conducted a study on the self-efficacy beliefs of teacher candidates towards STEM practices as a result of which it was concluded that the self-efficacy beliefs of teacher candidates towards STEM practices were relatively higher before taking a laboratory course on STEM practices. It was set forth in the study by Abac1 (2020) that the self-efficacies for STEM 
practices of science teacher candidates participating in STEM activities was higher than before the activity. The fact that primary school teacher candidates have high self-efficacy for STEM practices despite the absence of a STEM related course in their undergraduate curriculum coupled with the fact that they have not yet started their profession may be due to their lack of awareness of the complex structure of STEM education or the fact that they consider STEM practices as something they can already do (Hoy \& Spero, 2005). However, the critical thinking dispositions of teacher candidates were at a "good" level. It has been reported in many studies conducted for identifying the critical thinking dispositions of teacher candidates (Açışl1, 2015; Beşoluk \& Önder, 2010; Facione, Giancarlo, Facione, \& Gainen, 1995; Korkmaz, 2009; Kuvaç \& Koç, 2014; Özdemir, 2005; Saçlı ve Demirhan, 2008; Şen, 2009 ) that the teacher candidates have a moderate critical thinking disposition level; whereas it has been observed based on studies by Can and Kaymakçı (2015), Dutoğlu and Tuncel (2008), Şenlik, Balkan and Aycan (2011), Tümkaya (2011) and Zayıf (2008) that the disposition is quite low. Moreover, Kartal (2012) stated that the critical thinking disposition levels of science teacher candidates are above average; Hamurcu, Günay and Akamca Özyılmaz (2005) reported that science and primary school teacher candidates have strong and positive critical thinking dispositions; whereas Karalı (2012) indicated as a result of a study including primary school teacher candidates that the critical thinking dispositions of teacher candidates are at a good level. The findings of these studies illustrating that the critical thinking dispositions of teacher candidates are at a good level support the findings of the present study. This may be related with the inclusion of the "critical and analytical thinking" elective course to the primary school teaching undergraduate curriculum which enables students to acquire these thinking skills.

There is a positive, moderate and statistically significant correlation between self-efficacy for STEM practices and critical thinking disposition in the present study. Accordingly, it can be indicated that the critical thinking dispositions of teacher candidates increases with increasing self-efficacy for STEM practices. In other words, the critical thinking dispositions of teacher candidates decrease with decreasing self-efficacy for STEM practices. Science, technology, engineering, and mathematics fields included in STEM education aim to enable the individuals to strengthen their imaginations, conduct critical and scientific thinking and establish effective communication through cooperation (Tezel \& Yaman, 2017). Öztürk (2018) carried out a study examining the impact of STEM education on the critical thinking and problem-solving skills of teacher candidates as a result of which it was observed that the impact increases in a positive manner. Evcim and Topsakal (2019) conducted a study as a result of which it was expressed that STEM education increases the critical thinking disposition of individuals due to its engineering dimension and that the teachers who undergo STEM education have above average critical thinking disposition. It was concluded during the study by Hacığlu (2017) on science teacher candidates that STEM education increased the critical thinking disposition of teacher candidates and that such educations contribute to improving their critical thinking and scientific creativity skills. Hence, it can be indicated that significant contributions can be made to critical thinking dispositions of teacher candidates when they feel sufficient for conducting STEM activities.

In the meantime, a positive, moderate, and statistically significant correlation was observed between the self-efficacy for STEM practices and the sub-dimensions of critical thinking disposition which are "metacognition", "flexibility", "systematicity", "tenacity-patience" and "open mindedness". Metacognition which means that the individual realizes, monitors and controls the scientific processes; flexibility which means that a problem or situation should be taken into consideration from different perspectives; systematicity which means that 
individuals should make decisions not randomly but based on concrete data; open mindedness which means that the individual should take into consideration the opinions of others as well; patience which indicates resilience against difficult conditions and tenacity which is used for the efforts put forth to reach a specific goal are important factors for STEM education. In addition, it was observed that self-efficacy for STEM practices is a significant predictor of critical thinking disposition and its sub-dimensions. Self-efficacy for STEM practices explains $19 \%$ of tenacity and patience, $18 \%$ of systematicity, $17 \%$ of metacognition and $10 \%$ of flexibility and open mindedness. Even though STEM encompasses many disciplines, it is observed that design and engineering processes have been emphasized more in the 2018 science teaching curriculum. Whereas engineering and design processes require more imagination, patience, and tenacity. Therefore, it is expected from teachers to conduct STEM activities to have tenacity and patience. Similarly, Tezel and Yaman (2017) carried out a study during which it was emphasized that teachers who will provide STEM education should be patient, Şimşek (2019) conducted a study as a result of which it was indicated by some of the students who took part in the study that STEM activities contributed to their levels of patience. Thus, teachers should be patient towards their students during STEM activities, while students should not get bored of their activities immediately and should be perseverant and patient. Hacıoglu (2017) carried out a study during which it was concluded that STEM activities have a positive impact on the systematicity, truth seeking and open mindedness dimensions of the critical thinking disposition of teacher candidates. Moreover, teacher candidates most frequently defined systematicity as a decision-making strategy based on concrete information during the aforementioned study on the opinions of teacher candidates regarding the sub-dimensions of systematicity. Therefore, studies in literature on the impact of STEM on decision making skill (Azevedo, Martalock, \& Keser, 2015; Bozkurt, 2014; Ercan, 2014) indirectly support the findings of the present study when the decision-making process is taken into consideration as an outcome of critical thinking. This impact was observed to be positive during the conducted studies. Hence, it can be indicated that systematicity regarded as an important factor for conducting planned and careful research during the decision-making process is one of the significant characteristics that teachers who will conduct STEM activities. In addition, the engineering and engineering design processes included in STEM education make significant contributions to the metacognition skills of individuals (Mangold \& Robinson, 2013). It was observed as a result of a literature survey that the concept of metacognition is expressed as "thinking to think" (Baysal, Ayvaz, Çekirdekçi \& Malbeleği, 2013), "monitoring and controlling thinking" (Martinez, 2006), "learning strategy" (Eggen \& Kauchak, 2001) and "high level of thinking" (Candan, 2005). Baysal, Ayvaz, Çekirdekçi and Malbeleği (2013) and Öztürk and Serin (2020) carried out studies during which it was stated that the metacognitional awareness levels of primary school teacher candidates are high, while it was reported during the study by Özsoy, Çakıroğlu, Kuruyer and Özsoy (2010) that the awareness level is moderate. If students are continuing their studies during STEM activities in a planned and regular manner, if they are aware of what they know about the activity and the information they need and if they are able to organize all these factors it is an indication that the students are using metacognition strategy. In short, STEM disposition makes important contributions to the development of the highlevel cognitive skills of the students such as education planning and assessment or problem solving. In this regard, the primary school teachers who will contribute to their students for utilizing their metacognition skills and who will conduct the STEM activities in the classroom and thus the primary school teacher candidates should also have these skills. Self-efficacy for STEM practices predicts flexibility and open mindedness even if at a lower level compared with other variables. Flexibility as the ability to view situations from a different perspective is considered to be important for STEM education. While individuals with low flexibility have a 
certain thinking style, those with high flexibility levels have different thinking strategies (Sungur, 1997). Thus, it can be indicated that flexibility is one of the most distinctive characteristics of creative individuals. In addition, teacher candidates should have a creative personality in order to be successful especially in STEM education processes of engineering design, utilization or invention of new technologies. Hacioğlu (2017) carried out a study as a result of which it was concluded that STEM based activities make significant contributions to the scientific creativities of teacher candidates and the development of flexibility, originality and fluency which are sub-dimensions of scientific creativity. Moreover, it was emphasized in the aforementioned study that providing individuals with a free working environment along with various materials is important for the development of their scientific creativity and especially the dimensions of flexibility and originality. Whereas open mindedness is important in STEM education with regard to being tolerant to different opinions or taking into consideration the opinions of others when making decisions. Such that, STEM activities are generally conducted as group work. Hence, it is inevitable that different opinions will emerge during the decision-making stages of these activities. It is not important to have the group adopt the opinion of a certain individual but to make the best decision through discussing different opinions during the problem-solving process. Zayıf (2008) and Yüksel, Sar1-Uzun and Dost (2013) carried out studies during which it was reported that the dispositions of teacher candidates are positive in the open mindedness and analyticity sub-dimensions critical thinking disposition; whereas Dutoğlu and Tuncel (2008) stated that teacher candidates have positive dispositions in the open mindedness, analyticity and curiosity sub-dimensions. Even though self-efficacy for STEM practices was lower in the present study compared with the other variables, the fact that open-mindedness is among the variables it predicts supports the findings of the previous studies.

Moreover, a positive and high correlation was observed in the present study between critical thinking disposition and "self-efficacy belief in science education"; and a positive and low correlation was identified between critical thinking disposition and "outcome expectancy from science education". Together, these two predictors explain about $30 \%$ of the variance regarding critical thinking disposition. Efficacy beliefs have two different dimensions which are "self-efficacy" and "outcome expectancy". Self-efficacy is used to express beliefs regarding the personal competencies for a certain work or duty; while outcome expectancy is defined as personal beliefs in the effect of an action on achieving a particular outcome (Bandura, 1977). It was observed in the present study that the disposition towards critical thinking increases in teacher candidates with increasing self-efficacy beliefs. This acquired result is in accordance with the results of many previous studies in literature which examine the correlation between self-efficacy belief and critical thinking disposition (Artino, Anthony \& Stephens, 2009; Kuiper, 2002; Leung \& Kember, 2003; Phan, 2009; Wang \& Yi Wub, 2008).

The following suggestions can be made based on the findings of the present study:

- It was observed in the study and in certain previous studies in literature that the selfefficacy levels for STEM practices of teacher candidates are at a good level even though they did not take any STEM related courses. Hence, experimental studies for identifying the self-efficacy for STEM practices of teacher candidates can be conducted for supporting this finding.

- Even though an emphasis was made on STEM as part of the 2018 Science education curriculum, it is observed that the revised school teaching undergraduate program (2018) does not encompass a STEM related obligatory or elective course. Undergraduate programs may be revised again to include STEM and engineering 
design-based courses which will increase the self-efficacy for STEM practices and awareness of teacher candidates.

- STEM laboratories or STEM education centers can be established at universities.

- Considering that self-efficacy for STEM practices predicts flexibility and open mindedness at a statistically significant level even though at a lower level compared with other variables, group work may be included more frequently as part of the inclass activities which will make significant contributions to the flexibility and openmindedness skills of students.

\section{References}

Abacı, B. (2020). Bütünleştirilmiş FeTeMM etkinliklerinin fen bilgisi öğretmen adaylarının FeTeMM ile ilgili tutum ve özyeterliklerine etkisinin incelenmesi [Investigation of the effects of integrated STEM activities on attitudes and self-efficacy of science teacher candidates towards STEM]. (Master's thesis). University of Balıkesir, Balıkesir.

Açışlı, S. (2015). Öğretmen adaylarının öğrenme stilleri ve eleştirel düşünme eğilimlerinin incelenmesi [Investigation of teacher candidates' learning styles and critical thinking dispositions]. Necatibey Faculty of Education Electronic Journal of Science and Mathematics Education, 9(1), 23-48. https://doi.org/10.17522/nefefmed.57817

Aizikovitsh-Udi, E., \& Amit, M. (2011). Developing the skills of critical and creative thinking by probability teaching. Procedia Social and Behavioral Sciences, 15, 10871091. https://doi.org/10.1016/j.sbspro.2011.03.243

Artino, A. R., \& Stephens, J. M. (2009). Academic motivation and self-regulation: A comparative analysis of undergraduate and graduate students learning online. The Internet and Higher Education, 12(3), 146-151. https://doi.org/10.1016/j.iheduc.2009.02.001

Azevedo, F. S., Martalock, P. L., \& Keser, T. (2015). The discourse of design-based science classroom activities. Culturel Studies of Science Education, 10(2), 285-315. http://dx.doi.org/10.1007/s11422-013-9540-5

Bakırcı, H., \& Kutlu, E. (2018). Fen bilimleri öğretmenlerinin FeTeMM yaklaşımı hakkındaki görüşlerinin belirlenmesi [Determination of science teachers' views on STEM approach]. Turkish Journal of Computer and Mathematics Education, 9(2), 367-389. https://doi.org/10.16949/turkbilmat.417939

Bandura, A. (1977). Self-efficacy: Toward a unifying theory of behavioral change. Psychological Review, 84, 191-215. https://doi.apa.org/doi/10.1037/0033295X.84.2.191

Bandura, A. (1997). Self-efficacy: The exercise of control. New York: W. H. Freeman and Company.

Barak, M., \& Shakhman, L. (2008). Fostering higher-order thinking in science class: teachers' reflections. Teachers and Teaching: Theory and Practice, 14(3), 191-208. https://doi.org/10.1080/13540600802006079

Baysal, Z. N., Ayvaz, A., Çekirdekçi, S., \& Malbeleği, F. (2013). Sınıf öğretmeni adaylarının üstbilişsel farkındalıklarının farklı değişkenler açısından incelenmesi [An analysis of metacognitive awareness of pre-service elementary classroom teachers in terms of various variables]. Marmara University Atatürk Faculty of Education Journal of Educational Sciences, 37, 68-81.

Beşoluk, Ş., \& Önder, İ. (2010). Öğretmen adaylarının öğrenme yaklaşımları, öğrenme stilleri ve eleştirel düşünme eğilimlerinin incelenmesi [Investigation of teacher candidates' learning approaches, learning styles and critical thinking dispositions]. Elementary Education Online, 9(2), 679-693. http://ilkogretim-online.org.tr/ 
Boynukara, Z., Deniz, A. N., \& Tüysüz, M. (2020). Fen bilimleri öğretmenlerinin FeTeMM ile ilgili görüsslerinin incelenmesi [Investigation of the views of science teachers on STEM]. YYU Journal of Education Faculty, 17(1), 1204-1241. https://doi.org/10.33711/yyuefd.808779

Bozkurt, E. (2014). Mühendislik tasarım temelli fen eğitiminin fen bilgisi ögretmen adaylarının karar verme becerisi, bilimsel süreç becerileri ve sürece yönelik algilarina etkisi [The effect of engineering design based science instruction on science teacher candidates' decision making skills, science process skills and perception]. (Doctoral dissertation). University of Gazi, Ankara.

Bölükbaşı, G. \& Görgülü-Arı, A. (2019). Fen bilimleri öğretmenlerinin FeTeMM eğitimi ve etkinliklerine yönelik görüşleri [The views of science teachers about STEM education and activities] Academic Perspective Procedia, 2(1), 47-56. https://doi.org/10.33793/acperpro.02.01.11

Brown, P.L., Concannon, J. P., Marx, D., Donaldson, C. W., \& Black, A. (2016). An examination of middle school students' STEM self-efficacy with relation to interest and perceptions of STEM. Journal of STEM Education: Innovations and Research, 17(3), 27-38. https://www.learntechlib.org/p/193934/

Buechel, C. (2021). An investigation of the effects of self-efficacy on STEM implementation. (Curriculum and instruction undergraduate honors theses). University of Arkansas, Fayetteville. Retrieved from https://scholarworks.uark.edu/cieduht/24

Büyüköztürk, Ş. (2003). Sosyal bilimler için veri analizi el kitabı [Handbook for data analysis in social science]. Ankara: PegemA Publishing.

Can, Ş., \& Kaymakçı, G. (2015). Öğretmen adaylarının eleştirel düşünme eğilimleri [PreService teachers' critical thinking tendencies]. E-Journal of New World Sciences Academy, 10(2), 66-83.

Cho, B., \& Lee, J. (2013, November). The effects of creativity and flow on learning through the steam education on elementary school contexts. Paper presented at the International Conference of Educational Technology, Sejong University, South Korea.

Çevik, M., Danıştay, A., \& Yağcı, A. (2017). Ortaokul öğretmenlerinin FeTeMM (FenTeknoloji-Mühendislik-Matematik) farkındalıklarının farklı değişkenlere göre değerlendirilmesi (Evaluation of STEM awareness of secondary school teachers with various variables). Sakarya University Journal of Education, 7(3), 584-599.

Çolakoğlu, M. H., \& Günay-Gökben, A. (2017). Türkiye'de eğitim fakültelerinde FeTeMM (STEM) çalışmaları [STEM studies in Turkish faculties of education]. Journal of Research in Informal Environments, 3, 46-69.

Çorlu, M.S., Capraro, R.M., \& Capraro, M.M. (2014). Introducing STEM education: Implications for educating our teachers in the age of innovation. Education and Science, 39(171), 74-85. http://hdl.handle.net/11693/13203

Dembo, M. H. (2004). Motivation and learning strategies for college success: A selfmanagement approach (2nd ed.). Mahwah, NJ: Erlbaum

Dutoğlu, G., \& Tuncel, M. (2008). Aday öğretmenlerin eleştirel düşünme eğilimleri ile duygusal zekâ düzeyleri arasındaki ilişki [The relationship between candidate teachers' critical thinking tendencies and their emotional intelligence levels]. Bolu Abant Izzet Baysal University Journal of Faculty of Education, 8(1), 11-32.

Ennis, R. H. (1985). A logical basis for measuring critical thinking skills. Educational Leadership, 43(2), 44-48.

Ercan, S. (2014). Fen eğitiminde mühendislik uygulamalarının kullanımı: Tasarım temelli fen eğitimi [The use of engineering applications in science education: Design-based sceince education]. (Doctoral dissertation). University of Marmara, İstanbul. 
Ertuğrul-Akyol, B. (2020). STEM etkinliklerinin fen bilgisi ögretmen adaylarının bilgi işlemsel, eleştirel, yaratıcı düşünme ve problem çözme becerilerine etkisi [The effect of STEM activities on science teachers' computer, critical, creative thinking and problem solving skills]. (Doctoral dissertation). University of Erciyes, Kayseri.

Evcim, İ., \& Topsakal, Ü. U. (2019). STEM eğitimi alan öğretmenlerin eleştirel düşünme eğilimlerinin belirlenmesi [Determination of critical thinking tendency in STEM education field teachers]. The Journal of International Lingual Social and Educational Sciences, 5(2), 254-263. https://doi.org/10.34137/jilses.525872

Faber, M., Alanda, U., Eric, N., \& Wiebe, J.C. (2013). Student attitudes toward STEM: The development of upper elementary school and middle/high school student surveys. American Society for Engineering Education Annual Conference \& Exposition, 120, 6955-6976.

Facione, P. A., Giancarlo, C., Facione, N., \& Gainen, J. (1995). The disposition toward critical thinking. Journal of General Education, 44(1), 1-25.

Facione, P. A. (2007). Critical thinking: what it is and why it counts. Millbrae, CA: California Academic.

Field, A. (2009). Discovering statistics using SPSS. Dubai: Oriental Press.

Fraenkel, J.R., \& Wallen, N.E. (2009). How to design and evaluate research in education (7th ed.). New York: McGraw-Hill.

Friday Institute for Educational Innovation (2012). Teacher efficacy and beliefs toward STEM survey. Raleigh, NC: Author.

Fulton, K., Doerr, H., \& Britton, T. (2010). STEM teachers in professional learning communities: A knowledge synthesis. Washington DC: National Commission on Teaching and America's Future.

Gelen, B., Akçay, B., Tiryaki, A., \& Benek, İ. (2019). Fen bilimleri öğretmen adaylarının Fen-Teknoloji-Mühendislik-Matematik (FeTeMM)'e Yönelik Özyeterlik Ölçeği: Türkçe'ye uyarlama, geçerlik ve güvenirlik çalışması [Pre-service science teachers' self-efficacy toward STEM survey: An adaptation to Turkish, validity and reliability study]. Journal of Theory and Practice in Education, 15(1), 88-107. https://doi.org/10.17244/eku.395204

Gürbüz, S. (2019). AMOS ile yapisal eşitlik modellemesi [Structural equation modeling with AMOS]. Ankara: Seçkin Publishing.

Hacıoğlu, Y. (2017). Fen, teknoloji, mühendislik ve matematik (STEM) eğitimi temelli etkinliklerin fen bilgisi ögrretmen adaylarının eleştirel ve yaratıcı düşünme becerilerine etkisi [The effect of STEM education based activities on prospective science teachers' critical and creative]. (Doctoral dissertation). University of Gazi, Ankara.

Hacıömeroğlu, G. (2018). Examining elementary pre-service teachers' science, technology, engineering, and mathematics (STEM) teaching intention. International Online Journal of Educational Sciences, 10(1), 183-194. https://doi.org/10.15345/iojes.2018.01.014

Haciömeroğlu, G., \& Bulut, A. S. (2016). Entegre FeTeMM öğretimi yönelim ölçeği Türkçe formunun geçerlik ve güvenirlik çalışması [Integrative STEM teaching intention questionnaire: A validity and reliability study of the Turkish form]. Journal of Theory and Practice in Education, 12(2), 627-653.

Hamurcu, H., Günay, Y., \& Akamca Özyılmaz, G. (2005). Fen bilgisi ve sınıf öğretmenliği anabilim dalı öğrencilerinin eleştirel düşünme eğilimi profilleri [Critical thinking disposition profiles of science and primary school teaching department students]. Eurasian Journal of Educational Research, 20, 147-157. 
Hoy, A. W., \& Spero, R. B. (2005). Changes in teacher efficacy during the early years of teaching: a comparison of four measures. Teaching and Teacher Education, 21(4), 343-356. https://doi.org/10.1016/j.tate.2005.01.007

İnançlı, E., \& Timur, B. (2018). Fen bilimleri öğretmen ve öğretmen adaylarının STEM eğitimi hakkındaki görüşleri [Science teacher and teacher candidates' opinions about STEM education]. International Journal of Science and Education, 1(1), 48-66.

Karalı, Y. (2012). Eğitim fakültesi ögrencilerinin eleştirel düşünme eğilimleri (İnönü Üniversitesi Örneği) [Critical thinking disposition of students of college of education (The model of Inonu university)]. (Unpublished master's thesis). University of Inonu, Malatya.

Kartal, T. (2012). İlköğretim fen bilgisi öğretmen adaylarının eleştirel düşünme eğilimlerinin incelenmesi [Exploring of dispositions toward critical thinking in pre-service elementary science teachers]. Journal of Ahi Evran University Kırşehir Faculty of Education, 13(2), 279-297.

Kim, D. \& Bolger, M. (2017). Analysis of Korean elementary pre-service teachers' changing attitudes about integrated STEAM pedagogy through developing lesson plans. International Journal of Science and Mathematics Education, 15, 587-605. http://dx.doi.org/10.1007/s10763-015-9709-3

Kline, R. B. (2016). Principles and practice of structural equation modeling (4th ed.). London: The Guilford Press.

Koçulu, A., \& Topçu, M. S. (2021). Developing pre-service science teachers' self-efficacy for STEM practices through STEM education. Paper presented at the European Conference on Educational Research, Geneva. Abstract retrieved from https://eeraecer.de/ecer-programmes/conference/26/contribution/49983/

Korkmaz, Ö. (2009). Eğitim fakültelerinin öğrencilerin eleştirel düşünme eğilim ve düzeylerine etkisi [The influence of education faculties on students' critical thinking level and disposition]. Turkish Journal of Educational Sciences, 7(4), 879-902.

Kuiper, R. A. (2002). Enhancing metacognition through the reflective use of self-regulated learning strategies. The Journal of Continuing Education in Nursing, 33(2), 78-87. https://doi.org/10.3928/0022-0124-20020301-11

Kuvaç, M., \& Koç, I. (2014). Fen bilgisi öğretmen adaylarının eleştirel düşünme eğilimleri: İstanbul üniversitesi örneği [Preservice science teachers' critical thinking dispositions: İstanbul university sample]. Turkish Journal of Education, 3(2), 46-59. https://doi.org/10.19128/turje.181081

Leung, D. Y. P., \& Kember, D. (2003). The relationship between approaches to learning and reflection upon practice. Educational Psychology, 23(1), 61-71. https://doi.org/10.1080/01443410303221

Lodico, M., Spaulding, D., \& Voegtle, K. (2010). Methods in educational research: From theory to practice (2nd edition). San Francisco, CA: Jossey-Bass.

Luo, T., So, W. W. M., Li, W. C., \& Yao, J. (2020). The development and validation of a survey for evaluating primary students' self-efficacy in STEM activities. Journal of Science Education and Technology, 30, 418-419. https://doi.org/10.1007/s10956-02009882-0

Mangold, J., \& Robinson, S. (2013). The Engineering design process as a problem solving and learning tool in K-12 classrooms. Paper presented at the 120th ASEE Annual Conference \& Exposition, Atlanta. Abstract retrieved from http://escholarship.org/uc/item/8390918m

Martinez, E. M. (2006). What is metacognition? Phi Delta Kappan, 87(9), 696-699. https://doi.org/10.1177\%2F003172170608700916 
Meng, C. C., Idris N., \& Kwan L. (2014). Secondary students' perceptions of assessments in science, technology, engineering, and mathematics (STEM). Eurasia Journal of Mathematics, Science \& Technology Education, 10(3), 219-227. https://doi.org/10.12973/eurasia.2014.1070a

Meyrick, K. M. (2011). How STEM education improves student learning. Meridian K12 School Computer Technologies Journal, 14(1), 1-5.

Ministry of National Education (MoNE) (2018). Science lesson curriculum (primary and secondary school 3, 4, 5, 6, 7 and $8^{\text {th }}$ grades. https://mufredat.meb.gov.tr/ProgramDetay.aspx?PID=325

Önen-Öztürk, F. (2019). STEM uygulamalarına ilişkin görüşlerle bu uygulamanın bilimsel tutum ve fen ögretimi öz yeterlik inancı üzerine etkisi [Views on STEM Applications and their impact on scientific attitude and self-efficacy belief in science teaching]. Journal of Mehmet Akif Ersoy University Faculty of Education, 52, 1-38. https://doi.org/10.21764/maeuefd.409368

Özdamar, K. (2003). Modern bilimsel araştırma yöntemleri [Modern scientific research methods]. Eskişehir: Kaan Bookstore.

Özdemir, S. M. (2005). Üniversite öğrencilerinin eleştirel düşünme becerilerinin çeşitli etkenler açısından değerlendirilmesi [Evaluation of university students' critical thinking skills in terms of various factors]. Turkish Journal of Educational Sciences, 3(3), 297-316.

Özsoy, G., Çakıroğlu, A., Kuruyer, H. G., \& Özsoy, S. (2010). Sınıf öğretmeni adaylarının üstbilişsel farkındalık düzeylerinin bazı değişkenler bakımından incelenmesi [Examining the metacognitive awareness levels of primary school teacher candidates in terms of some variables]. Paper presented at the 9th National Primary School Teaching Symposium, Elazı̆ . Abstract retrieved from https://pegem.net/Akademi/sempozyumbildiri_detay.aspx?id=121254

Öztürk, N., Yılmaz-Tüzün, Ö., \& Çakır-Yıldırım, B. (2019). Öğretmen adaylarının fen eğitiminde STEM uygulamalarına yönelik öz-yeterlik inanç ve görüşlerinin incelenmesi [Investigation of preservice teachers' self-efficacy beliefs and views regarding STEM applications in science education]. Trakya Journal of Education, 9(4), 649-665.

Öztürk, S. C. (2018). STEM eğitiminin fen bilgisi ögretmen adaylarının problem çözme ve eleştirel düşünme becerileri üzerine etkisi [The effects of student education on the problem solving and critical thinking skills of science teachers]. (Master Thesis). University of Erzincan Binali Yıldırım, Erzincan.

Öztürk, S. \& Serin, M. K. (2020). Sınıf öğretmeni adaylarının üstbilişsel farkındalıkları ile matematik öğretmeye yönelik kaygılarının incelenmesi [Examination of pre-service primary school teachers' metacognitive awareness with anxiety towards mathematics teaching]. Kastamonu Educational Journal, 28(2), 1013-1025. https://doi.org/10.24106/kefdergi.705074

Pallant, J. (2016). SPSS survival manual: A step by step guide to data analysis using SPSS program (6th ed.). London, UK: McGraw-Hill Education.

Phan, H. P. (2009). Relations between goals, self-efficacy, critical thinking, and deep processing strategies: A path analysis. Educational Psychology, 29, 777- 799. https://doi.org/10.1080/01443410903289423

Ring, E. A., Dare, E. A., Crotty, E. A., \& Roehrig, G. H. (2017). The evolution of teacher conceptions of STEM education throughout an intensive professional development experience. Journal of Science Teacher Education, 28(5), 444-467. https://doi.org/10.1080/1046560X.2017.1356671 
Saçlı, F., \& Demirhan, G. (2008). Beden eğitimi ve spor öğretmenliği programında öğrenim gören öğrencilerin eleştirel düşünme düzeylerinin saptanması ve karşılaştırılması [A determination and comparison of critical thinking levels of students in physical education teacher training program]. Hacettepe Journal of Sport Sciences, 19(2), 92110.

Saleh, A.H. (2016). A Proposed unit in the light of STEM approach and its effect on developing attitudes toward (STEM) and problem solving skills for primary students. International Interdisciplinary Journal of Education, 5(7), 186-217.

Sanders, M. E. (2013). Integrative STEM education defined. Blacksburg, VA: Virginia Tech University.

Semerci, N. (2000). Kritik düşünme ölçeği [Scale of critical thinking]. Education and Science, 25(116), 23-26.

Semerci, N. (2016). Eleştirel düşünme eğilimi (EDE) ölçeğinin geliştirilmesi: Geçerlik ve güvenirlik revize çalışması [The development of critical thinking disposition scale (CTHD): Study on the revision of validity and reliability]. Turkish Studies, 11(9), 725740. http://dx.doi.org/10.7827/TurkishStudies.9573

Stinson, K., Harkness, S. S., Meyer, H., \& Stallworth, J. (2009). Mathematics and science integration: Models and characterizations. School Science and Mathematics, 109(3), 153-161. https://doi.org/10.1111/j.1949-8594.2009.tb17951.x

Sungur. N. (1997). Yaratıcı düşünce [Creative thinking]. İstanbul: Evrim Publishing.

Şahin, A., Ayar, M. C., \& Adıgüzel, T. (2014). Fen, Teknoloji, Mühendislik ve Matematik içerikli okul sonrası etkinlikler ve öğrenciler üzerindeki etkileri [STEM related afterschool program activities and associated outcomes on student learning]. Educational Sciences: Theory and Practice, 14(1), 297-322.

Şen, Ü. (2009). An evaluation about Turkish teacher candidates' critical thinking attitude's in terms of difference variable. Journal of World of Turks, 1(2), 69-89.

Şenlik, N. Z., Balkan, Ö., \& Aycan, Ş. (2011). Öğretmen adaylarının eleştirel düşünme becerileri: Muğla üniversitesi örneği [Critical thinking dispositions of pre-service teacher: Muğla university example]. Celal Bayar University Journal of Science, 7(1), 67-76.

Şimşek, F. (2019). FeTeMM etkinliklerinin öğrencilerin fen tutum, ilgi, bilimsel süreç becerileri üzerine etkisi ve öğrenci görüşleri [Effect of STEM activities on students' scientific process skills, science interest, attitude and student opinions]. Turkish Journal of Computer and Mathematics Education, 10(3), 654-679. https://doi.org/10.16949/turkbilmat.470261

Tabachnick, B. G., \& Fidell, L. S. (2013). Using multivariate statistics (6th ed.). Boston: Allyn and Bacon.

Tezel, Ö., \& Yaman, H. (2017). FeTeMM eğitimine yönelik Türkiye'de yapılan çalışmalardan bir derleme [A review of studies on STEM education in Turkey]. Journal of Research in Education and Teaching, 6(1), 2146-9199.

Thomas, T. A. (2014). Elementary teachers' receptivity to integrated science, technology, engineering, and mathematics (STEM) education in the elementary grades. (Unpublished doctoral dissertation). University of Nevada, Reno.

Timur, B., \& Belek, F. (2020). FeTeMM etkinliklerinin öğretmen adaylarının öz-yeterlik inançlarına ve FeTeMM eğitimi yönelimlerine etkisinin incelenmesi [Investigation of the effects of STEM activities on pre-service teachers' self-efficacy beliefs and their STEM intention levels]. PAU Journal of Education, 50, 315-332.

Tümkaya, S. (2011). Fen bilimleri öğrencilerinin eleştirel düşünme eğilimleri ve öğrenme stillerinin incelenmesi [Comparison of college science major students' learning styles 
and critical thinking disposition]. Journal of Ahi Evran University Faculty of Education, 12(3), 215-234.

Wagner, T. (2008). Rigor redefined. Educational Leadership, 66(2), 20-24.

Wai, J., Lubinski, D., \& Benbow, C. P. (2010). Accomplishment in science, technology, engineering, and mathematics (STEM) and its relation to stem educational dose: a 25year longitudinal study. Journal of Educational Psychology, 102(4), 860-871. https://psycnet.apa.org/doi/10.1037/a0019454

Wang, S. L., \& Wu, P. Y. (2008). The role of feedback and self-efficacy on web-based learning: The social cognitive perspective. Computers \& Education, 51(4), 15891598. https://doi.org/10.1016/j.compedu.2008.03.004

Yaman, C., Özdemir, A., \& Akar-Vural, R. (2018). STEM uygulamaları öğretmen öz-yeterlik ölçeğinin geliştirilmesi: Bir geçerlik ve güvenirlik çalışması [Development of the teacher self-efficacy scale for STEM practices: A validity and reliability study]. Adnan Menderes University, Journal of Institute of Social Sciences, 5(2), 93-104. https://doi.org/10.30803/adusobed.427718

Yeh, Y. C. (1997). Teacher training for critical thinking instruction via a computer simulation. (Doctoral dissertation). University of Virginia, Virginia.

Yeh, Y. C. (2004). Nurturing reflective teaching during critical-thinking instruction in computer simulation program. Computers and Education, 42, 2, 181-194. https://doi.org/10.1016/S0360-1315(03)00071-X

Yüksel, N. S., Sarı-Uzun, M., \& Dost, Ş. (2013). Matematik öğretmen adaylarının eleştirel düşünme eğilimleri [Critical thinking tendencies of prospective mathematics teachers]. Hacettepe University Journal of Education, Özel Say1 (1), 393-403.

Zayıf, K. (2008). Öğretmen adaylarının eleştirel düşünme eğilimleri [Critical thinking dispositions of teacher canditates]. (Unpublished master's thesis). University of Abant İzzet Baysal, Bolu.

Zollman, A. (2012). Learning for STEM literacy: STEM literacy for learning. School Science and Mathematics, 112(1), 12-19. https://doi.org/10.1111/j.1949-8594.2012.00101.x 